\title{
ZONASI TINGKAT KERAWANAN BANJIR PADA RUAS BEKAS SUNGAI DI KABUPATEN SUKOHARJO
}

\author{
Agra Kurnia Saputra1, Dian Hudawan Santoso ${ }^{2}$, Andi Renata Ade Yudono ${ }^{3}$ \\ Program Studi Teknik Lingkungan, Fakultas Teknologi Mineral, UPN Veteran Yogyakarta \\ Jalan SWK No 104 (Lingkar Utara), Condong Catur, Yogyakarta, 55281, Indonesia \\ Email: dian.hudawan@upnyk.ac.id
}

\begin{abstract}
Abstrak
Kecamatan Tawangsari dan Kecamatan Sukoharjo, Kabupaten Sukoharjo, Provinsi Jawa Tengah merupakan wilayah yang dilalui proyek pelurusan Sungai Bengawan Solo. Setelah dilakukan pelurusan Sungai Bengawan Solo timbul masalah baru, yaitu munculnya beberapa ruas bekas sungai. Pada awal tahun 2006 terjadi bencana banjir di sekitar ruas bekas sungai akibat masuknya aliran dari Sungai Bengawan Solo melalui ruas bekas sungai sehingga menggenangi permukiman dan lahan pertanian. Berdasarkan hal tersebut, ruas bekas sungai belum dikelola dengan baik sehingga menimbulkan masalah lingkungan. Penelitian ini bertujuan untuk mengetahui tingkat kerawanan banjir di kawasan sekitar ruas bekas sungai di lokasi penelitian. Metode yang digunakan dalam pengumpulan data adalah metode survei dan pemetaan lapangan serta metode skoring dan pembobotan. Skoring dan pembobotan dilakukan terhadap beberapa parameter, yaitu curah hujan, kemiringan lereng, jenis tanah, penggunaan lahan, elevasi, dan jarak wilayah dengan sungai (buffer). Zonasi kerawanan banjir didapatkan dengan metode skoring dan pembobotan berdasarkan parameter tersebut. Hasil penelitian menunjukkan di lokasi penelitian terdiri dari 3 zona kerawanan banjir yaitu kerawanan rendah sebesar 66,7\%, kerawanan sedang sebesar 27,75\%, dan kerawanan tinggi sebesar 5,55\% dari total luas daerah penelitian.
\end{abstract}

Kata kunci: Kerawanan Banjir, Ruas Bekas Sungai, Zonasi

\begin{abstract}
Tawangsari Subdistrict and Sukoharjo Subdistrict, Sukoharjo Regency, Central Java Province are the areas that have passed the Bengawan Solo River alignment project. After rectifying the Bengawan Solo River, a new problem arose, namely the emergence of several ex-river segments called billabong. In the early of 2006 there was a flood around the former river section due to the influx of flow from the Solo River along the former river section so that it inundated settlements and agricultural land. Based on this, the former river section has not been managed well, causing environmental problems. This study aims to determine the use of the former river section as a flood disaster control engineering. This study aims to determine the level of flood vulnerability in the area around the former river section of the study location. The methods used in data collection are survey and field mapping methods as well as scoring and weighting methods. Scoring and weighting are carried out on several parameters, namely rainfall, slope, soil type, land use, elevation, and distance of the area from the river (buffer). Zoning of flood hazard is obtained by scoring and weighting methods based on these parameters. The research area has three flood vulnerability zones, namely low vulnerability with $66,7 \%$, moderate vulnerability with $27,75 \%$, and high vulnerability level with $5,55 \%$ of the total area of the study area.
\end{abstract}

Key words: Flood Hazard, Billabong, Zoning 


\section{PENDAHULUAN}

Berbagai permasalahan yang selama ini muncul di Sungai Bengawan Solo antara lain adalah erosi, kegiatan penambangan, pencemaran dan banjir (Prasetya, 2010). Namun, permasalahan utama yang sering terjadi pada sungai Bengawan Solo adalah bencana banjir (Putri, 2010). Tahun 1990 hingga 1994 dilakukan pelurusan Sungai Bengawan Solo Hulu di daerah Sukoharjo, Surakarta, dan Karanganyar (Suryanta, 2018). Pelurusan sungai secara fisik menimbulkan paling sedikit dua perubahan pada morfologi sungai, yaitu terbentuknya alur sungai baru dan terbentuknya alur sungai yang tidak dialiri lagi yang dikenal masyarakat dengan istilah sungai mati. Dalam Keputusan Menteri Pekerjaan Umum No. 18/PRT/2009 Tentang Pedoman Pengalihan Alur Sungai Dan/ Atau Pemanfaatan Ruas Bekas Sungai, dan lahan kering dengan sistem drainase yang buruk. Pada daerah penelitian, sebagian ruas bekas sungai digunakan sebagai lahan bercocok tanam pada musim kemarau dan penampung limpasan air pada musim hujan.

Ruas bekas sungai merupakan bekas lembah sungai yang berbentuk cekungan sehingga memiliki karakteristik, yaitu tergenang air yang dapat mencapai ketinggian $1 \mathrm{~m}$ hingga 1,5 $\mathrm{m}$ atau bahkan lebih pada musim hujan. Ruas bekas sungai akan dipenuhi oleh tumbuhan liar seperti eceng gondok pada musim hujan (Gambar 1). Pada musim kemarau, ruas bekas sungai akan mengalami penurunan ketinggian air bahkan dibeberapa lokasi kondisinya mengering. Kondisi tanah pada ruas bekas sungai di lokasi penelitian sebagian besar tetap jenuh air meskipun pada musim kemarau.

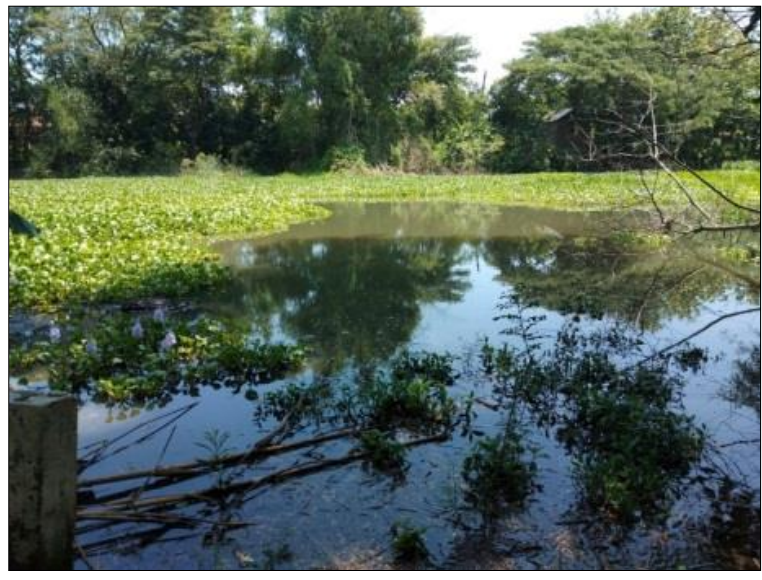

Gambar 1. Kondisi Genangan Air Pada Ruas Bekas Sungai Pada Musim Hujan

istilah sungai yang tidak berfungsi sebagai alur sungai untuk mengalirkan air sungai disebut ruas bekas sungai.

Kecamatan Tawangsari dan Kecamatan Sukoharjo, Kabupaten Sukoharjo, Jawa Tengah merupakan salah satu wilayah yang dilalui proyek pelurusan Sungai Bengawan Solo karena merupakan daerah rawan bencana banjir. Setelah dilakukan pelurusan Sungai Bengawan Solo daerah tersebut tidak mengalami banjir tahunan namun menimbulkan masalah baru, yaitu munculnya beberapa ruas bekas sungai. Sebagian ruas bekas sungai merupakan lahan basah berupa genangan
Pada tahun 2006 terjadi bencana banjir di sekitar ruas bekas sungai akibat masuknya aliran air dari Sungai Bengawan Solo ke ruas bekas sungai sehingga menggenangi permukiman dan lahan pertanian warga serta menyebabkan satu rumah roboh. Berdasarkan hal tersebut, ruas bekas sungai belum dikelola dengan baik sehingga menimbulkan masalah lingkungan.

\section{METODE PENELITIAN}

Metode pengumpulan data dalam penelitian ini adalah metode survei dan pemetaan lapangan yaitu melakukan 
pengamatan dan pengukuran secara langsung di lapangan untuk mengetahui kondisi eksisting pada lokasi penelitian. (Syaripudin, 2014).Penyusun menggunakan metode survey dan pemetaan untuk crosscheck data sekunder yang telah didapatkan sebelumnya yang kemudian di cek dengan kondisi faktual di lapangan (Santoso, 2019). Pada penelitian ini metode survei dan pemetaan juga digunakan dalam melakukan penelusuran banjir yang terjadi pada tahun 2006.

Metode pengharkatan dan pembobotan ini digunakan untuk dapat mengetahui tingkat kerawanan banjir pada daerah penelitian. Skoring dan pembobotan yang dilakukan pada penelitian ini mengacu pada Kusumo, 2016 yang melakukan pembobotan menggunakan metode expertise judgment yaitu pendapat para ahli. Parameter yang digunakan diantaranya kemiringan lereng, curah hujan, penggunaan lahan, jenis tanah, elevasi, dan jarak wilayah dengan sungai (buffer).

Tabel 1. Parameter Kemiringan Lereng

\begin{tabular}{ccccc}
\hline $\begin{array}{c}\text { Kelas } \\
\text { Lereng }\end{array}$ & $\begin{array}{c}\text { Unit } \\
\text { Relief }\end{array}$ & Warna & Skor & $\begin{array}{c}\text { Bob } \\
\text { ot }\end{array}$ \\
\hline $0 \%-$ & Datar & $\begin{array}{c}\text { Hijau } \\
\text { Tua }\end{array}$ & 9 & \\
$8 \%$ & & Hijau & 7 & \\
$8 \%-$ & Landai & Muda & & 10 \\
$15 \%$ & Bergelom & Kuning & 5 & $\%$ \\
$15 \%-$ & bang & Orange & 3 & \\
$25 \%$ & Curam & Oran & & \\
$40 \%$ & Sangat & $\begin{array}{c}\text { Merah } \\
\text { Muda }\end{array}$ & 1 & \\
$>40 \%$ & Curam & Mun & & \\
\hline
\end{tabular}

Sumber: Chow (1968) dalam Kusumo (2016)

Kemiringan lereng mempengaruhi arah, laju, dan konsentrasi limpasan air hujan. Hal ini karena daerah dengan kemiringan lereng yang datar akan semakin besar potensinya terakumulasi air dari pada daerah dengan kemiringan lereng terjal. Mengetahui kemiringan lereng di daerah penelitian dilakukan dengan melakukan metode pola kontur pada peta topografi yang telah dilakukan Cross Check lapangan. Pada daerah penelitian kemiringan lereng hanya terdapat dua kelas, yaitu kemiringan lereng datar dan landai.

Tabel 2. Parameter Curah Hujan

\begin{tabular}{|c|c|c|c|}
\hline No & \multicolumn{2}{|c|}{ Curah Hujan } & Bobot \\
\hline & Kelas (mm) & Skor & \\
\hline 1. & $>2500$ & 9 & \\
\hline 2. & $2001-2500$ & 7 & $15 \%$ \\
\hline 3. & $1501-2000$ & 5 & $15 \%$ \\
\hline 4. & $1000-1500$ & 3 & \\
\hline 5. & $<1000$ & 1 & \\
\hline
\end{tabular}

Sumber: Kusumo (2016)

Parameter curah hujan akan mempengaruhi laju infiltrasi dan debit rencana banjir. Pada daerah penelitian curah hujan hanya terdapat satu kelas, yaitu 1572 $\mathrm{mm}$. Data curah hujan yang digunakan adalah data curah hujan hujan 20 Tahun (1999 - 2018). Data curah hujan pada daerah penelitian didapatkan dari Balai Penyuluhan Pertanian Kecamatan Tawangsari.

Tabel 3. Parameter Penggunaan Lahan

\begin{tabular}{|c|c|c|c|}
\hline No. & \multicolumn{2}{|c|}{ Penggunaan Lahan } & Keterangan \\
\hline & Kelas & Skor & \\
\hline 1. & $\begin{array}{l}\text { Lahan } \\
\text { terbuka, } \\
\text { badan air, } \\
\text { tambak }\end{array}$ & 9 & \\
\hline 2. & Permukiman, & 7 & \\
\hline 3. & $\begin{array}{l}\text { Perkebunan, } \\
\text { tegalan }\end{array}$ & 5 & $25 \%$ \\
\hline 4. & $\begin{array}{c}\text { Kebun } \\
\text { campur, } \\
\text { semak belukar }\end{array}$ & 3 & \\
\hline 5. & Hutan & 1 & \\
\hline
\end{tabular}

Sumber: Kusumo (2016)

Parameter penggunaan lahan akan mempengaruhi laju limpasan air dan infiltrasi apabila terjadi hujan. Daerah dengan penggunaan lahan seperti permukiman dan sawah memiliki tingkat skor paling besar, hal ini karena tingkat infiltrasi pada penggunaan lahan tersebut rendah karena tanah telah bersifat kedap air. 
Tabel 4. Parameter Jenis Tanah

\begin{tabular}{cccc}
\hline No. & Jenis Tanah & Bobot \\
\cline { 2 - 3 } Kelas & Skor & \\
1. & Vertisol, oxisol & 9 & \\
2. & Alfisol, ultisol, & 7 & \\
& molisol & & $10 \%$ \\
3. & Inceptisol & 5 & \\
4. & Entisol, histosol & 3 & \\
5. & Spodosol, andisol & 1 & \\
\hline
\end{tabular}

Sumber: Kusumo (2016)

Penetapan skor pada parameter tanah didasarkan pada terstur dari jenis tanah. Pada daerah penelitian hanya terdapat satu jenis tanah yaitu tanah aluvial yang masuk dalam kelas entisol berdasarkan padanan Klasifikasi Tanah Nasional (BBSDLP) dengan Soil Taksonomi Tahun 2014 (Subardja et al, 2014).

Tabel 5. Parameter Elevasi

\begin{tabular}{cccc}
\hline No. & \multicolumn{2}{c}{ Elevasi } & Keterangan \\
\cline { 1 - 3 } & $\begin{array}{c}\text { Kelas } \\
\text { (mdpl) }\end{array}$ & Harkat & \\
1. & $0-20$ & 9 & $20 \%$ \\
2. & $21-50$ & 7 & \\
3. & $51-100$ & 5 & \\
4. & $101-300$ & 3 & \\
5. & $>300$ & 1 & \\
\hline
\end{tabular}

Sumber: Kusumo (2016)

Parameter elevasi berpengaruh terhadap terjadinya banjir, hal ini didasarkan pada sifat air yaitu mengalir ketempat yang lebih rendah. Pada daerah yang memiliki daerah dengan elevasi rendah akan berpotensi lebih besar terkena banjir daripada daerah yang memiliki elevasi yang lebih tinggi. Pada daerah penelitian elevasi berkisar antara 87 hingga 96 mdpl.

Tabel 6. Parameter Buffer

\begin{tabular}{|c|c|c|c|}
\hline No. & \multicolumn{2}{|c|}{ Buffer } & Keterangan \\
\hline & $\begin{array}{l}\text { Kelas } \\
\text { (meter) }\end{array}$ & Harkat & \\
\hline 1. & $0-25$ & 9 & \\
\hline 2. & $25-50$ & 7 & \\
\hline 3. & $50-75$ & 5 & $20 \%$ \\
\hline 4. & $75-100$ & 3 & \\
\hline 5. & $>100$ & 1 & \\
\hline
\end{tabular}

Sumber: Kusumo (2016)
Semakin dekat jarak suatu wilayah dengan sungai (buffer), maka peluang banjir akan semakin tinggi. Pada daerah penelitian kondisi alur sungai baru telah terdapat tanggul di bagian kanan dan kirinya, sehingga memperkecil potensi banjir.

Berdasarkan penelusuran banjir di daerah penelitian, banjir disebabkan karena masuknya air dari alur sungai baru menuju alur sungai lama (backwater), oleh karena itu, parameter buffer dihitung dari alur sungai lama. Parameter buffer diberikan bobot tertinggi karena berdasarkan penelusuran banjir yang pernah terjadi adalah disekitar alur sungai lama.

Formula yang digunakan dalam proses overlay dengan menggunakan metode aritmatika adalah sebagai berikut:

$$
\begin{aligned}
K B= & (15 x C H)+(10 x K L)+(10 x J T)+(25 x P L) \\
& (20 \times E)+(20 \times B)(1)
\end{aligned}
$$

Keterangan :

$\mathrm{CH}$ : Curah Hujan

KL : Kemiringan Lereng

JT : Jenis Tanah

PL : Penggunaan Lahan

E : Elevasi

B : Buffer

Penetapan daerah rawan banjir dilakukan dengan menganalisis hasil dari hasil keseluruhan parameter. Pada penelitian ini dilakukan modifikasi kelas kerawanan banjir berdasarkan Kusumo (2016) supaya sesuai dengan kondisi eksisting dilapangan. Pada penelitian ini, klasifikasi daerah rawan banjir dibagi ke dalam lima kelas. Menurut Saputra (2013), dalam menentukan interval tingkat kerawanan banjir dalam pengklasifikasian menggunakan rumus sebagai berikut:

$\mathrm{I}=\frac{\mathrm{R}}{\mathrm{K}}$

Keterangan:

$\mathrm{I}=$ Lebar interval kelas

$\mathrm{R}=$ Range $/$ rentang beda nilai data tertinggi dengan data terendah

$\mathrm{K}=$ Jumlah interval kelas 
Tabel 7. Klasifikasi Tingkat Kerawanan Banjir

\begin{tabular}{|c|c|c|}
\hline No. & $\begin{array}{c}\text { Interval } \\
\text { Kelas }\end{array}$ & Keterangan Kelas \\
\hline 1. & $440-526$ & $\begin{array}{c}\text { Kerawanan } \\
\text { Rendah }\end{array}$ \\
\hline 2. & $527-613$ & $\begin{array}{c}\text { Kerawanan } \\
\text { Sedang }\end{array}$ \\
\hline 3. & $614-700$ & $\begin{array}{c}\text { Kerawanan } \\
\text { Tinggi }\end{array}$ \\
\hline
\end{tabular}

\section{HASIL DAN PEMBAHASAN}

Evaluasi tingkat kerawanan bencana banjir dilakukan dengan analisis tumpang susun terhadap parameter yang digunakan peneliti. Parameter yang digunakan pada penelitian ini mengacu pada Jurnal Sting Vol.1 tahun 2016 (Kusumo, 2016). Sebelum dilakukan tumpang susun tersebut, setiap parameter penentu dilakukan analisis skoring dan pembobotan terlebih dahulu. Tingkat kerawanan bencana banjir ditentukan dengan semakin besar total skor setiap parameter maka semakin besar tingkat kerawanan bencana banjir di daerah penelitian.

Curah hujan merupakan salah satu faktor pemicu terjadinya bencana banjir, diantaranya adalah mempengaruhi besar debit aliran Sungai Bengawan Solo. Pada penelitian ini hanya digunakan data curah hujan Kecamatan Tawangsari saja, hal ini dikarenakan daerah penelitian seluas 165,127 ha.

Kemiringan lereng pada daerah penelitian hanya terdapat 2 kelas, yaitu datar dengan kemiringan $0-6 \%\left(0^{\circ}-3,43^{\circ}\right)$ dan landai $8-15 \% \quad\left(4,57^{\circ}-8,53^{\circ}\right)$. Daerah penelitian memiliki bentuklahan dataran aluvial dengan ketinggian 87 - 96 mdpl yang merupakan daerah yang cenderung datar sehingga semakin besar potensi untuk menjadi daerah genangan dan terjadi banjir.

Jenis tanah pada daerah penelitian hanya ada satu jenis, yaitu tanah aluvial. Penetapan parameter jenis tanah ini didasarkan pada tekstur tanah. Hal ini disebabkan semakin halus tekstur tanah menyebabkan air limpasan permukaan yang berasal dari hujan maupun luapan dari badan air akan sulit meresap atau terinfiltrasi ke dalam tanah, sehingga terjadi penggenangan. Tekstur tanah pada daerah penelitian bertekstur lempung pada permukaan, lempung debuan, dan pasir di bagian dalam berdasarkan pengeboran tanah. Tekstur tanah lempung berakibat lambatnya proses infiltrasi yang mempengaruhi lama genangan di daerah penelitian.

Penggunaan lahan merupakan salah satu parameter yang berperan pada besarnya air limpasan permukaan. Pada daerah penelitian terdapat penggunaan lahan permukiman, persawahan, tegalan, badan air, dan tanggul, namun yang mendominasi adalah penggunaan lahan permukiman dan tegalan.

Parameter elevasi berpengaruh terhadap luasan terjadinya bencana banjir, hal ini dikarenakan sifat air yang mengalir ke daerah yang lebih rendah. Daerah penelitian memiliki elevasi 87 - 96 mdpl sehingga hanya terdapat satu kelas, yaitu kelas elevasi 51 - $100 \mathrm{mdpl}$.

Parameter buffer atau jarak wilayah terhadap sungai atau badan air merupakan parameter yang paling berpengaruh di daerah penelitian. Hal ini dikarenakan bencana banjir yang terjadi pada tahun 2006 tersebut merupakan backwater dari Sungai Bengawan Solo yang masuk melalui ruas bekas sungai dan menggenangi daerah disekitar ruas bekas sungai.

Kemudian untuk mendapatkan zonasi tingkat kerawanan bencana banjir, semua parameter yaitu curah hujan, kemiringan lereng, jenis tanah, penggunaan lahan, elevasi, dan buffer dilakukan overlay/tumpang susun. Semua parameter kemudian dilakukan pengharkatan dan pembobotan. Setelah itu dilakukan pengklasifikasian kelas zonasi tingkat kerawanan bencana banjir dengan tiga zona, yaitu kerawanan rendah, kerawanan sedang, dan kerawanan tinggi. Untuk lebih jelasnya pengklasifikasian kelas zonasi tingkat kerawanan bencana banjir dapat dilihat pada Tabel 8 sedangkan persebaran zonasi dapat dilihat pada Gambar 2 berikut: 
Tabel 8. Zonasi Tingkat Kerawanan Banjir

\begin{tabular}{cccc}
\hline No & Zonasi Tingkat Kerawanan Banjir & Luasan $(\mathrm{Ha})$ & Persentase $(\%)$ \\
1. & Kerawanan Rendah & 110,14 & 66,7 \\
2. & Kerawanan Sedang & 45,83 & 27,75 \\
3. & Kerawanan Tinggi & 9,16 & 5,55 \\
& Total & $165,13 \mathrm{Ha}$ & $100 \%$ \\
\hline
\end{tabular}

Sumber : Hasil Analisis Penelitian, 2019
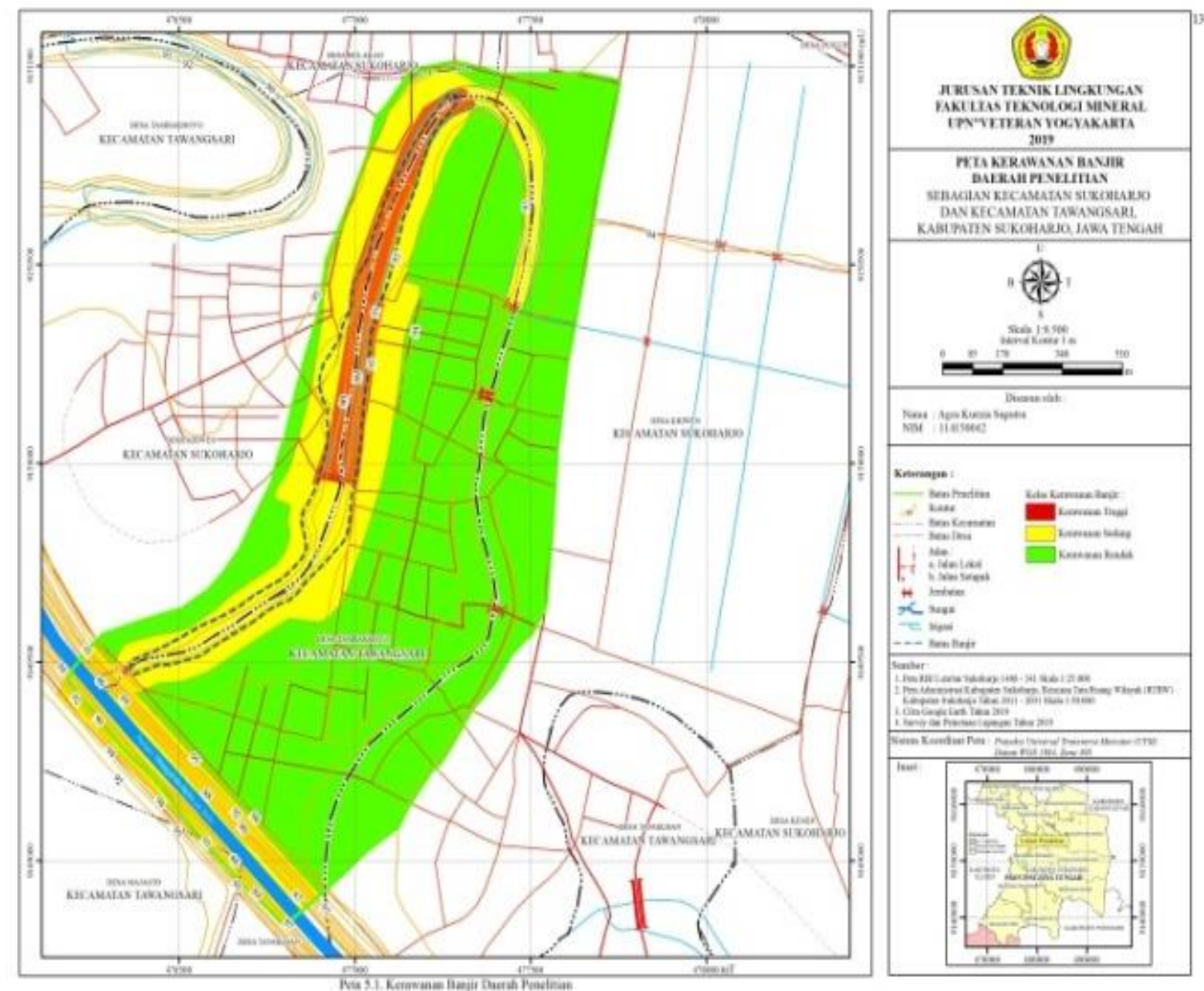

Gambar 2. Peta Tingkat Kerawanan Banjir

Zona kerawanan rendah dapat dikatakan sebagai kawasan yang paling aman terhadap kemungkinan terjadi banjir. Hal ini disebabkan karena daerah ini berada lebih dari 75 meter berdasarkan buffer ruas bekas sungai dengan penggunaan lahan berupa tegalan, sawah, dan permukiman. Berdasarkan hasil analisis tingkat kerawanan banjir, kawasan dengan kerawanan rendah di daerah penelitian seluas 110,14 ha atau mencakup 66,7\% dari total luas daerah penelitian.
Zona kerawanan sedang merupakan kawasan yang termasuk potensial kritis terhadap kemungkinan terjadi banjir. Kawasan dengan zona kerawanan sedang berada pada jarak 25 - 50 meter berdasarkan buffer ruas bekas sungai dengan penggunaan lahan berupa permukiman dan tegalan. Berdasarkan hasil analisis tingkat kerawanan banjir, daerah dengan kerawanan sedang di daerah penelitian seluas 45,83 ha atau mencakup $27,75 \%$ dari total luas daerah penelitian. 
Zona kerawanan tinggi merupakan kawasan yang termasuk kritis terhadap kemungkinan terjadi banjir. Kawasan dengan zona kerawanan tinggi berada pada jarak 0 - 25 meter berdasarkan buffer ruas bekas sungai dengan penggunaan lahan berupa permukiman. Berdasarkan hasil analisis tingkat kerawanan banjir, daerah dengan kerawanan tinggi di daerah penelitian seluas 9,16 ha atau mencakup $5,55 \%$ dari total luas daerah penelitian.

\section{KESIMPULAN}

Penentuan tingkat kerawanan banjir dipengaruhi oleh parameter kemiringan lereng, curah hujan, penggunaan lahan, jenis tanah, elevasi, dan jarak wilayah dengan sungai (buffer). Kawasan dengan kerawanan tinggi berada pada jarak 0 - 25 meter berdasarkan buffer ruas bekas sungai dengan penggunaan lahan berupa permukiman, kawasan dengan kerawanan sedang berada pada jarak 25 - 50 meter berdasarkan buffer ruas bekas sungai dengan penggunaan lahan berupa permukiman dan tegalan, dan kawasan dengan kerawanan rendah berada pada jarak lebih dari 75 meter berdasarkan buffer ruas bekas sungai. Berdasarkan hal tersebut, perlu adanya penelitian lanjutan terkait pengelolaan ruas bekas sungai pada zona kerawanan tinggi maupun zona kerawanan sedang.

\section{DAFTAR PUSTAKA}

Atmaka, FX. Nanang Agus Tri. (2004). Evaluasi normalisasi sungai Bengawan Solo hulu dengan konsep eko-hidraulik. Skripsi. Jurusan Teknik Sipil Fakultas Teknik Universitas Sebelas Maret. Surakarta.

Kepmen PU (2009). Keputusan Menteri Pekerjaan Umum No. 18/PRT/2009 Tentang Pedoman Pengalihan Alur Sungai Dan/ Atau Pemanfaatan Ruas Bekas Sungai. Pekerjaan Umum.
DOI: $10.24114 /$ ig.v12i01.14390

e-ISSN: 2549-7057 | p-ISSN: 2085-8167

Kusumo, Probo dan Evi Nursani. (2016). Zonasi Tingkat Kerawanan Banjir Dengan Sistem Informasi Geografis Pada DAS Cidurian, Kabupaten Serang, Banten. Jurnal String Vol. 1 No. 1 ISSN: 2527 9661.

Prasetya, D. (2010). Visualisasi Kerusakan Lingkungan Sungai Bengawan Solo. Skripsi. Jurusan Ilmu Komunikasi Fakultas Ilmu Sosial dan Politik Universitas Sebelas Maret. Surakarta.

Putri, D.R., Tunjung Wijayanto Suharso., Fadly Usman .(2010). Arahan Konservasi Wilayah Sungai Bengawan Solo Yang Melalui Perkotaan Bojonegoro. Jurnal Tata Kota dan Daerah Vol2. No 2. Hal 75 - 81. Santoso, DH. (2019). Penanggulangan Bencana Banjir Berdasarkan Tingkat Kerentanan dengan Metode Ecodrainage Pada Ekosistem Karst di Dukuh Tungu, Desa Girimulyo, Kecamatan Panggang, Kabupaten Gunungkidul, DIY. Jurnal Geografi Vo 16. No 1. Hal 7- 15

Saputra, Roni. (2013). Statistik Terapan Dalam Ilmu Kesehatan Masyarakat. Tugas Akhir. Program Studi D-IV Analis Kesehatan Stikes Perintis Sumbar. Padang

Subardja, D., S. Ritung, M. Anda, Sukarman, E. Suryani, dan R.E. Subandiono. (2016). Petunjuk Teknis Klasifikasi Tanah Nasional. Bogor: Balai Besar Penelitian dan Pengembangan Sumberdaya Lahan Pertanian, Badan Penelitian dan Pengembangan Pertanian.

Suryanta, J., Nursugi., Irmadi Nahib.(2018). Identifikasi Morfologi Sungai Dengan Citra Satelit Dalam Restorasi Sungai (Studi Kasus Bengawan Solo Hulu). Prosiding Seminar Nasional Geografi UMS IC 2018

Syaripudin, Akhmad. (2014). Pengantar Survey dan Pengukuran. Jakarta : Direktorat Pembinaan SMK 